\title{
Detection of major viruses infecting shallot and molecular characterization of Onion yellow dwarf virus from several locations in Indonesia
}

\author{
HERI HARTI ${ }^{1, \vartheta}$, SRI HENDRASTUTI HIDAYAT ${ }^{2}$, SOBIR ${ }^{1,3}$, SURYO WIYONO ${ }^{1,2}$ \\ ${ }^{1}$ Center for Tropical Horticulture Studies, Institut Pertanian Bogor. Jl. Pajajaran, Kampus IPB Baranangsiang, Bogor 16144, West Java, Indonesia. \\ Tel.: +62-251-8326881, "email: heri.harti@yahoo.co.id \\ ${ }^{2}$ Department of Plant Protection, Faculty of Agriculture, Institut Pertanian Bogor. Jl. Meranti, Kampus IPB Darmaga, Bogor 16680, West Java, Indonesia \\ ${ }^{3}$ Department of Agronomy and Horticulture, Faculty of Agriculture, Institut Pertanian Bogor. Jl. Meranti, Kampus IPB Darmaga, Bogor 16680, West \\ Java, Indonesia
}

Manuscript received: 7 February 2020. Revision accepted: 27 March 2020.

\begin{abstract}
Harti H, Hidayat SH, Sobir, Wiyono S. 2020. Detection of major viruses infecting shallot and molecular characterization of Onion yellow dwarf virus from several locations in Indonesia. Biodiversitas 21: 1697-1701. Research was conducted to identify main viruses infecting shallot in several regions in Indonesia and to further characterize genetic variation of Onion yellow dwarf virus (OYDV). Field survey was conducted in Central Java (Brebes), East Java (Probolinggo), West Sumatera (Alahan Panjang), West Nusa Tenggara (Bima), and South Sulawesi (Enrekang). Virus detection from field samples was conducted by dot immunobinding assay. This detection confirmed that infection of OYDV, Shallot yellow stunt virus (SYSV), Shallot latent virus (SLV), and Garlic common latent virus (GarCLV) has occurred in all field with incidence ranged from 20 to $93.5 \%, 2$ to $93 \%, 21.5$ to $80 \%$, and 2 to $80.5 \%$, respectively. The specific primers of Nib gene successfully amplified DNA fragments of OYDV from all locations. Sequencing of DNA fragments revealed that the amplified product was $351 \mathrm{bp}$. Sequence analysis indicated that the present OYDV isolates from Indonesia shared homology from 82 to $95 \%$; and they had homology from 81 to $95 \%$ with OYDV isolates from other countries. The similarity of OYDV isolates from different geographical locations reflected the movements of seed bulbs among and within countries. The phylogenetic tree also revealed that OYDV isolates from different countries did not group together indicating their diverse origin.
\end{abstract}

Keywords: DIBA, Nib gene, phylogenetic tree, sequence analysis, sequence homology

\section{INTRODUCTION}

Shallot (Allium cepa L. var. ascalonicum) is an important horticultural commodity in Indonesia due to its significant contribution to the economic development of most regions in the country. Farmers grow shallot both in the highlands, such as in Solok-West Sumatera and Enrekang-South Sulawesi and in the lowlands, such as in Brebes-Central Java, Probolinggo-East Java, and BimaWest Nusa Tenggara. Shallot cultivars grown by farmers in each production center varies, for example, farmers in Brebes prefer to grow cv. Bima, while farmers in Probolinggo, Bima, Solok, and Enrekang prefer cv. Biru Lancor, Super Phillips, SS Sakato, and Katumi, respectively. One major constraint related to crops' productivity that is commonly faced by shallot farmers is disease problems.

The main diseases reported from shallot production regions in Indonesia are purple blotch (Alternaria porri), basal rot (Fusarium oxysporum), downy mildew (Peronospora destructor), anthracnose (Colletotrichum gloeosporioides) and several viral diseases (Semangun 2010). Infection of Potyviruses (OYDV/Onion yellow dwarf virus, SYSV/Shallot yellow stripe virus, and LYSV/Leek yellow stripe virus) and Carlaviruses (SLV/Shallot latent virus dan GarCLV/Garlic common latent virus) has been reported previously, and the incidence reached $11.2 \%$ to $78 \%$ (Sutarya et al. 1993; Arisuryanti et al. 2008; Kadwati and Hidayat 2015; Swari et al. 2015; Gunaeni et al. 2018). Among those viruses, infection of OYDV was always recorded very high and becomes a major concern for several regions (Sutarya et al. 1993; Bagi et al. 2012; Kadwati and Hidayat 2015; Wulandari et al. 2015; Gunaeni et al. 2018; Saputri et al. 2018).

In general, most shallot farmers in Indonesia use seed bulbs as propagative materials. High demands of shallot both as seed bulbs and consumption drive high mobility of shallot bulbs across regions as well as countries. This caused some risks to the spread of viral diseases since most viruses transmitted through tubers or bulbs. Shallot viruses, including OYDV, SYSV, SLV, and GarCLV have been detected from bulbs collected from Java island, i.e. East Java (Brebes) and West Java (Cirebon, Majalengka, Kuningan and Bandung) (Wulandari et al. 2015; Saputri et al. 2018). The list is hypothetical will increase since the growing area of shallot production has spread widely in Indonesia. Therefore, it is very important to identify major viruses infecting shallot from wider location in Indonesia. This research was conducted to detect viruses from shallot bulbs collected from different islands in Indonesia and to identify genetic variation of OYDV specifically to study the potential of disease spread through bulbs. 


\section{MATERIALS AND METHODS}

\section{Study area}

Field survey was conducted in Indonesia includes Central Java (Brebes), East Java (Probolinggo), West Sumatera (Alahan Panjang), West Nusa Tenggara (Bima), and South Sulawesi (Enrekang) from September 2016 to May 2017. The field survey was done by observing the symptoms of a virus in the crop. Virus detection was conducted from Feb 2018 to March 2019 at Laboratory of Plant Virology, Department of Plant Protection, Faculty of Agriculture and Laboratory of Molecular at Center for Tropical Horticultural Studies-LPPM, IPB University, Bogor, Indonesia.

\section{Procedures}

\section{Collection of plant samples}

Samples were obtained from shallot production regions in Indonesia, a total of 10 shallot fields were visited in each region. Each field was divided into 10 blocks, each containing 10 clusters of shallot which were taken randomly as plant samples. At harvesting time, bulbs were collected from each plant samples; then all bulbs were taken to laboratory. In the laboratory, bulbs are dried about 2 months to break dormancy. After that, bulbs were grown for further examination, i.e. virus detection by dot immunobinding assay (DIBA) and reverse transcriptionpolymerase chain reaction (RT-PCR).

\section{Virus detection using DIBA}

Bulbs collected from the fields were grown, then leaf samples were taken out 30 days later. Leaf samples were macerated in Tris buffer saline (TBS) to yield plant extracts. Leaf extracts were spotted onto nitrocellulose membrane; when the spot was dried up the membrane was processed following the protocol described by Asniwita (2012). The antibodies used in virus detection by DIBA consisted of specific antibodies to GarCLV, SLV, OYDV, and SYSV. Positif reaction between antibody and virus target in the membrane indicated by the development of purple mark on the area where plant extracts were spotted. The reaction was stopped by soaking the membrane in $\mathrm{dH}_{2} \mathrm{O}$. The incidence or frequency of infection of each virus target was determined based on the ratio between number of samples giving positive reaction and the total number of samples tested (200 samples)

\section{Virus amplification by Reverse Transcription - Polymerase Chain Reaction (RT-PCR)}

Extraction of total RNA from leaf samples was conducted following method described by Doyle dan Doyle (1987) with a few modifications. As much as $0.1 \mathrm{~g}$ of shallot leaf was ground in liquid nitrogen and $500 \mu \mathrm{L}$ of extraction buffer containing $1 \% 2-\beta$ - mercaptoethanol was added. Leaf extracts were transferred into $20 \mathrm{~mL}$ microtubes and incubated at $65^{\circ} \mathrm{C}$ for $30 \mathrm{~min}$. The tubes were flipped every $10 \mathrm{~min}$ to ease the lithic process. The tubes were kept at room temperature for $2 \mathrm{~min}$, then 500 $\mu \mathrm{L}$ mix of chloroform: isoamyl alcohol $(24: 1 \mathrm{v} / \mathrm{v})$ was added. The tubes were vortexed for $5 \mathrm{~min}$, then centrifuged at $11000 \mathrm{rpm}$ for $15 \mathrm{~min}$. The supernatant was transferred to new tubes and 0.1 volume of sodium acetate $\left(\mathrm{CH}_{3} \mathrm{COOH}\right.$ $3 \mathrm{M} \mathrm{pH}$ 5.2) was added; isopropanol as much as $2 / 3$ total volume of supernatant and $\mathrm{CH}_{3} \mathrm{COOH}$ was added; then the tubes were incubated at $-20{ }^{\circ} \mathrm{C}$ overnight. After centrifugation at $11000 \mathrm{rpm}$ for $15 \mathrm{~min}$, the supernatant was discarded and the pellet was washed using $500 \mu \mathrm{L}$ of $70 \%$ ethanol with centrifugation at $8000 \mathrm{rpm}$ for $5 \mathrm{~min}$. The pellet was air-dried for $1 \mathrm{hr}$ and then resuspended in 50 $\mu \mathrm{L}$ of TE buffer ( $\mathrm{pH}$ 8).

Synthesis and amplification of cDNA were carried out using MyTaq ${ }^{\mathrm{TM}}$ One-Step RT-PCR Kit (Bioline). The composition of the reaction consisted of $8.75 \mu \mathrm{L}$ Nuclease free water, $12.5 \mu \mathrm{L}$ My Taq, $1 \mu \mathrm{L}$ of $10 \mathrm{uM}$ each primer (OYDV-F2/OYDV-R2), $0.5 \mu \mathrm{L}$ Ribosafe inhibitor, 0.25 $\mu \mathrm{L}$ Reverse transcriptase, and $1.0 \mu \mathrm{L}$ total RNA. Specific primers for OYDV, i.e. OYDV-F2 (5'AAYTGGACIATGATGGAYG-3') dan OYDV-R2 (5'CTTTCCGTGTCCTCTTC-3') were obtained from Dr. Andrew Geering (QAAFI, University of Queensland). The primers amplified part of Nib gene with targeted amplicon of approximately $350 \mathrm{bp}$. Amplification program was carried out as follows: 1 cycle of reverse transcription at $50^{\circ} \mathrm{C}$ for $20 \mathrm{~min}, 1$ cycle of pre denaturation at $95^{\circ} \mathrm{C}$ for 1 min, 35 cycles consisted of denaturation at $95^{\circ} \mathrm{C}$ for $10 \mathrm{sec}$, annealing at $56^{\circ} \mathrm{C}$ for $10 \mathrm{sec}$, extension at $72^{\circ} \mathrm{C}$ for $30 \mathrm{sec}$, and final extension at $72^{\circ} \mathrm{C}$ for $2 \mathrm{~min}$. Visualization of amplified fragments was conducted using $1.5 \%$ agarose gel in $0.5 x$ TAE buffer.

\section{DNA sequencing and analysis}

Amplified DNA fragments were sent to First BASE, Malaysia for sequencing. Nucleotide homology analysis was conducted using Bio Edit 7.05 (http://mbio.ncsu.edu/ BioEdit/bioedit.html). Phylogenetic tree was constructed using ClustalX Bio Edit version 7.05 and MEGA V6.0 within neighbor-joining algorithm method and bootstrap 1000 repetition (Tamura et al. 2013).

\section{RESULTS AND DISCUSSION}

\section{Virus detection based on DIBA}

Detection of viruses confirmed that infection of OYDV, SYSV, SLV, and GarCLV has occurred in all fields. Incidence of OYDV, SYSV, SLV, and GarCLV ranged from 20 to $93.5 \%, 2$ to $93 \%, 21.5$ to $80 \%$, and 2 to $80.5 \%$, respectively. In general, infection of OYDV was high in all locations, except in Bima (Figure 1). The incidence of viruses is lower in Bima probably was due to source of shallot seed used by the farmers. Most farmers in Bima planted local cultivar, i.e. cv Superphillip, which is only circulated internally in the region. This fact indicates that introduction of viruses through seed mobility from one region to another may become the source of disease spread. The highest virus incidence was found in Enrekang, followed by Brebes, Probolinggo, Solok, and Bima (Figure 1). The high incidence of viruses in Enrekang, Brebes, and Probolinggo is thought to be caused by the origin of seed. The seed bulbs used in Enrekang are cv Katumi which 
were purchased from traders in Nganjuk, while farmers in Brebes and Probolinggo planted cv Bima and cv Biru Lancur which were produced by themselves. It was reported before that virus infection was very high in Enrekang, Brebes, and Probolinggo (Gunaeni et al. 2011; Kurniawan and Suastika 2013; Swari et al. 2015; Wulandari et al. 2015).

\section{Amplification of OYDV and sequence analysis}

Virus target for amplification by RT-PCR was OYDV since this virus has been reported as the most predominant virus on Allium globally, including in Indonesia (Sutarya et al. 1993; Elnagar et al. 2011; Gunaeni et al. 2011; Bagi et al. 2012; Kadwati dan Hidayat 2015; Wulandari et al. 2015). The specific primers of $\mathrm{Nib}$ gene successfully detected OYDV in naturally infected shallot bulbs from all locations. The primer combination amplified a fragment of approximately $350 \mathrm{bp}$ in almost all samples indicating the presence of OYDV in the tested samples. Band intensity was varied from one sample to another probably due to differences of virus concentration on each sample (Figure 2). Ten DNA fragments, i.e. 2 isolates representing each geographical location were selected for further confirmation by sequencing. Sequencing of DNA fragments revealed that the amplified product was $351 \mathrm{bp}$ and each sequence was then submitted to GenBank (Table 1).

Sequence analysis showed that the present OYDV isolates from Indonesia shared homology from 82 to $95 \%$. They also shared high sequence homology with OYDV isolates from other countries, i.e. from 81 to $95 \%$; and maximum sequence homology was shared between isolate from Brebes and from India (Table 2). High sequence homology among OYDV isolates indicated low sequence diversity. Since shallot in Indonesia is mainly propagated through bulbs, the similarity of OYDV isolates from different geographical locations probably reflected the movements of seed bulbs within the country or even between countries.

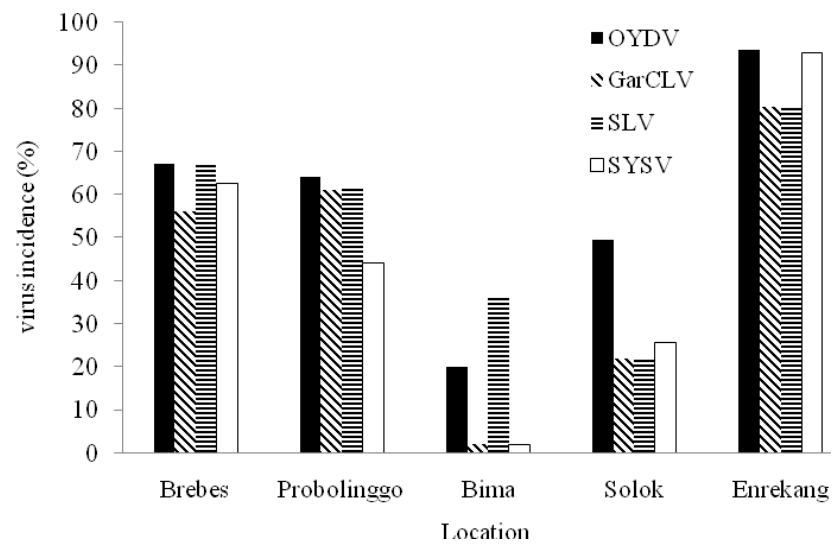

Figure 1. Incidence of main viruses on shallot bulbs from several locations in Indonesia based on detection using DIB method

Table 1. List of OYDV isolates used for nucleotide sequence analysis

\begin{tabular}{lll}
\hline Isolate & Origin & $\begin{array}{l}\text { GenBank } \\
\text { accession }\end{array}$ \\
\hline Brebes7 & Brebes: Kersana & LC473029 \\
Brebes9 & Brebes: Kersana & LC473030 \\
Probolinggo6 & Probolinggo: Leces & LC473031 \\
Probolinggo14 & Probolinggo: Tegal Siwalan & LC473032 \\
Solok5 & Alahan panjang: Padang Laweh & LC473033 \\
Solok9 & Alahan Panjang: Koto Kecik & LC473034 \\
Bima 16 & Bima: Monta & LC473035 \\
Bima 18 & Bima: Monta & LC473036 \\
Enrekang 2 & Enrekang: Ballah & LC473037 \\
Enrekang 3 & Enrekang: Ballah & LC473038 \\
India & India & KP862053 \\
Iran & Iran & GU295138 \\
Vietnam & Vietnam & DQ925454 \\
Australia & Australia & HQ258894 \\
Spanyol & Spanyol & JX433019 \\
\hline
\end{tabular}
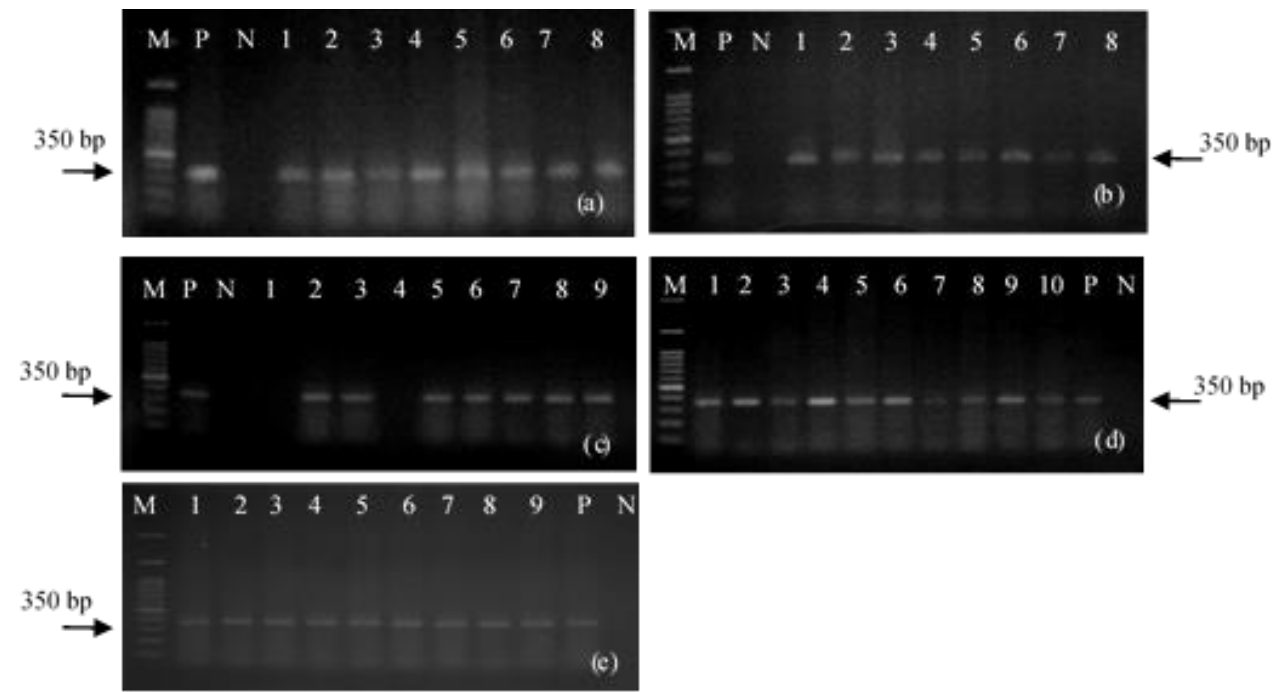

Figure 2. Reverse transcription-polymerase chain reaction (RT-PCR) amplification of OYDV from Brebes (A), Probolinggo (B), Bima (C), Solok (D), and Enrekang (E). Lane M, 100 bp DNA marker; lane P, positive control; lane N, negative control; lane 1 to 10, shallot bulbs. The approximately 350 bp bands in lanes 1 to 10 was indicative of OYDV infection 
Table 2. Sequence homology (\%) of Nib gene nucleotide of Onion yellow dwarf virus isolates

\begin{tabular}{|c|c|c|c|c|c|c|c|c|c|c|c|c|c|c|c|c|c|}
\hline \multirow{2}{*}{ No. } & \multirow{2}{*}{ Sequences } & \multicolumn{16}{|c|}{ Homology (\%) } \\
\hline & & 1 & 2 & 3 & 4 & 5 & 6 & 7 & 8 & 9 & 10 & 11 & 12 & 13 & 14 & 15 & 16 \\
\hline 1 & LC473029.Brebes7 & ID & & & & & & & & & & & & & & & \\
\hline 2 & LC473030.Brebes9 & 93 & ID & & & & & & & & & & & & & & \\
\hline 3 & LC473031.Probolinggo6 & 86 & 86 & ID & & & & & & & & & & & & & \\
\hline 4 & LC473032.Probolinggo14 & 82 & 83 & 89 & ID & & & & & & & & & & & & \\
\hline 5 & LC473033.Solok5 & 83 & 83 & 89 & 88 & ID & & & & & & & & & & & \\
\hline 6 & LC473034.Solok9 & 83 & 84 & 90 & 88 & 94 & ID & & & & & & & & & & \\
\hline 7 & LC473035.Bima16 & 85 & 86 & 90 & 87 & 95 & 94 & ID & & & & & & & & & \\
\hline 8 & LC473036.Bima18 & 85 & 85 & 89 & 87 & 91 & 91 & 95 & ID & & & & & & & & \\
\hline 9 & LC473037.Enrekang2 & 84 & 85 & 89 & 87 & 95 & 95 & 95 & 95 & ID & & & & & & & \\
\hline 10 & LC473038.Enrekang3 & 84 & 85 & 89 & 87 & 93 & 93 & 97 & 93 & 95 & ID & & & & & & \\
\hline 11 & KP862053.India & 95 & 93 & 86 & 82 & 83 & 83 & 85 & 85 & 84 & 84 & ID & & & & & \\
\hline 12 & GU295138.Iran & 91 & 88 & 86 & 82 & 82 & 82 & 84 & 84 & 83 & 84 & 90 & ID & & & & \\
\hline 13 & JX433019.Spain & 88 & 87 & 85 & 81 & 83 & 83 & 86 & 85 & 85 & 85 & 87 & 89 & ID & & & \\
\hline 14 & GQ475380.Argentina & 88 & 89 & 85 & 81 & 82 & 84 & 85 & 85 & 85 & 85 & 90 & 89 & 88 & ID & & \\
\hline 15 & DQ925454.Vietnam & 90 & 90 & 86 & 82 & 81 & 83 & 84 & 84 & 83 & 84 & 92 & 94 & 87 & 90 & ID & \\
\hline 16 & HQ258894.Australia & 91 & 89 & 85 & 81 & 82 & 84 & 85 & 86 & 84 & 84 & 90 & 91 & 87 & 91 & 93 & ID \\
\hline
\end{tabular}

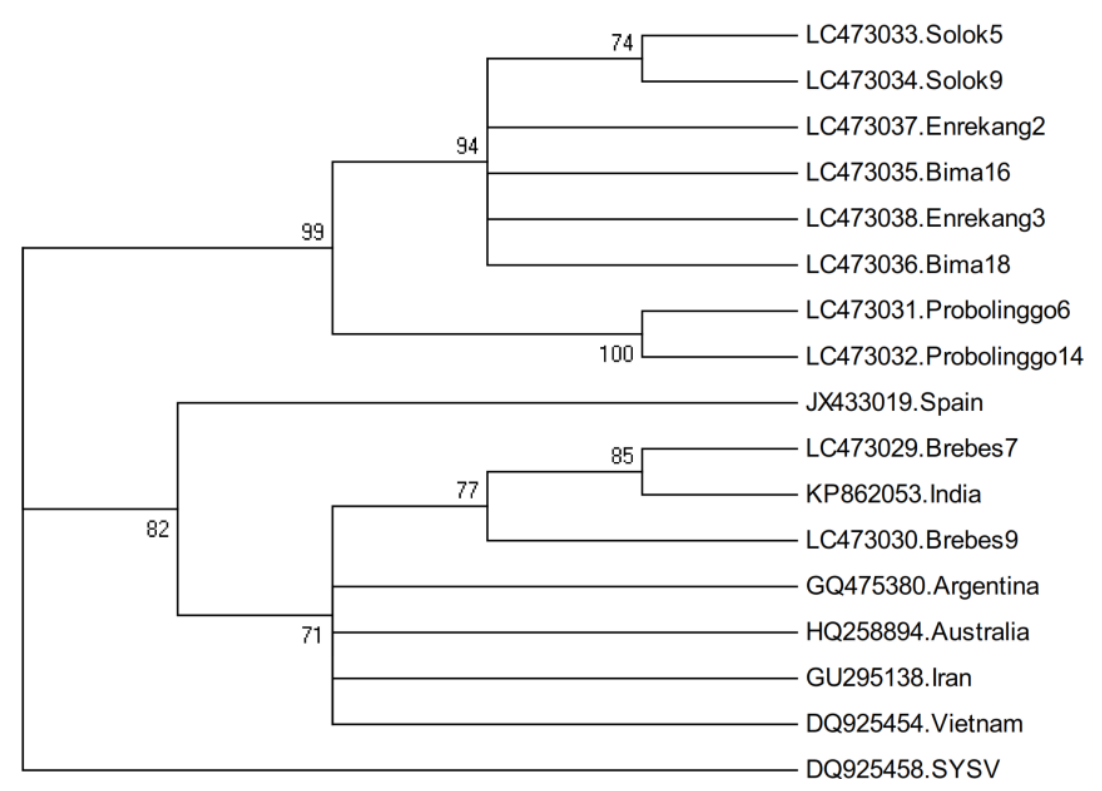

Figure 3. Phylogenetic tree of nucleotide sequences of Nib gene of Onion yellow dwarf virus from Indonesia (10 isolates), Argentina, Australia, India, Iran, Spain, and Vietnam (1 isolate each) and Shallot yellow stripe virus (SYSV) from Vietnam. Isolates with boxes are present isolates

The high homology of OYDV was also reported by Soliman et al. (2012). OYDV-EG Egyptian isolate (HM473189) has high homology (82 to 96\%) compared to 10 OYDV isolates from other countries ( 2 isolates China, 2 isolates UK, 2 isolates Japan, 2 isolates India, 1 isolate Australia, 1 isolate Argentine). Furthermore, Manglli et al. (2014) reported genetic variation of OYDV; the homology of nucleotides among OYDV isolates from garlic in Italy was very high (more than 99.3\%), while the nucleotide homology between OYDV isolates from Italy and those from Germany (JX433020), Argentina (JX433019) and Sudan (KF623541) were $94 \%, 92 \%$, and $87 \%$, respectively. High sequence homology was also reported between OYDV isolates from India and those from
Australia, i.e. 98\% (Verma et al. 2015). Similarly, Baghalian et al. (2010) reported that among OYDV isolates from Iran shared 79 to $99 \%$ homology of the nucleotide sequence of coat protein gene, while with OYDV isolates from other countries Iran isolates shared 79 to $98 \%$ identity.

\section{Phylogenetic analysis of OYDV nucleotides}

Phylogenetic analysis of the nucleotide of NIb gene of OYDV revealed that all OYDV isolates used in this study can be differentiated into 2 big groups. Most of the present Indonesian isolates of OYDV belong to the same group, except 2 isolates from Brebes which belong to the same group with isolate from India. The phylogenetic tree also 
revealed that OYDV isolates from different countries did not group together indicating their diverse origin (Figure 3). García-Arenal et al. (2001) suggested that genetic variation on virus could occur through mutation or recombination. Furthermore, studies have indicated that virus evolution could happen due to the adaptation towards susceptibility of environment, host plant, and insect vector (Agrios 2005).

In conclusion, four major viruses infecting shallot, i.e. OYDV, SYSV, SLV, and GarCLV were detected from field samples from different geographical locations in Indonesia. The use of shallot bulbs from previous planting season as seed source for the following season may contribute to the spread and distribution of this viral diseases. Infection of OYDV on shallot is considered high. Based on the nucleotide sequence analysis, it was revealed that the present OYDV isolates from Indonesia shared high sequence homology among each other and with other isolates from different countries as well.

\section{ACKNOWLEDGEMENTS}

The author would like to thank the Ministry of Research, Technology and Higher Education of Indonesia for the scholarship granted for the first author. Gratitude for Center for Tropical Horticulture Studies, IPB University for the research funding through Institutional Research and University Outstanding Applied Research under contract No. 079/SP2H/LT/DRPM/II/2016 and No. 1701/IT3.11/ $\mathrm{PN} / 2018$ respectively.

\section{REFERENCES}

Agrios N. 2005. Plant Pathology. 4th ed. Elsevier Academic Press, New York.

Arisuryanti T, Daryono BS. 2008. Observasi dan identifikasi virus yang menginfeksi bawang merah di Jawa. J Perlindungan Tanaman Indones. 14 (2): 55-62. [Indonesian]

Asniwita, Hidayat SH, Suastika G, Sujiprihati S, Susanto S, Hayati I. 2012. Exploration of weak isolates of Chili veinal mottle Potyvirus from chili peppers in Jambi, West Sumatra, and West Java. J Hort 22 (2): 181-186
Baghalian K, Kim OK, Natzuaki KT. 2010. Molecular variability and genetic structure of the population of Onion yellow dwarf virus infecting garlic in Iran. Virus Genes 41: 282-291.

Bagi F, Stojsin V, Budakov D, Salma MAE, Varga JG. 2012. Effect of Onion yellow dwarf virus (OYDV) on yield components of fall garlic (Allium sativum L.) in Serbia. Afr J Agric Res 7 (15): 2386-2390.

Doyle JJ, Doyle JL. 1987. A rapid DNA isolation of procedure for small quantities of fresh leaf tissue. Phytochem Bull 19: 11-19.

Elnagar S, Kader MA, El Wahab AS. 2011. Effect of natural infection with Onion yellow dwarf virus (OYDV) on yield of onion and garlic crops in Egypt. J Life Sci 5: 634-638.

García-Arenal F, Fraile A, Malpica JM. 2001. Variability and genetic structure of plant virus populations. Ann Rev Phytopathol 39:157186.

Gunaeni N, Wulandari AW, Duriat AS, Muharam A. 2011. Incidence of bulb-borne virus disease on thirteen varieties of shallots from West Java and Central Java. J Hort 21 (2): 164-172.

Gunaeni N, Karyadi AK, Adiyoga W. 2018. Detection of viral diseases on shallot from Brebes and Cirebon districts and their spread using the RT-PCR techniques. J Hort 28 (2): 229-238.

Kurniawan A, Suastika G. 2013. Detection and identification of plant viruses on shallot. J Fitopatol Indones 9 (2): 47-52.

Kadwati, Hidayat SH. 2015. Detection of main viruses infecting shallot and garlic in West and Central Java. J Fitopatol Indones 11 (4): 121127. [Indonesian]

Manglli A, Mohammed HS, EL Hussein AE, Agosteo GE, Albanese G, Tomassoli L. 2014. Molecular analysis of the 3' terminal region of Onion yellow dwarf virus from onion in southern Italy. Phytopathol Mediterr 53 (3): 438-450.

Saputri AS, Tondok ET, Hidayat SH. 2018. Incidence of viruses and fungi on True Shallot Seed and shallot bulb. J Fitopatol Indones 14 (6): 222- 228 .

Semangun H. 2010. Horticultural Crop Diseases in Indonesia. 4th ed. Gadjah Mada University Press, Yogyakarta. [Indonesian]

Soliman AM, Sabry YM, Mahmoud-Rehab AD. 2012. Molecular characterization of Onion yellow dwarf virus (Garlic isolate) with production $\mathrm{f}$ virus-free plantlets. Intl J Virol 8 (1): 61-70.

Sutarya R, van Vreden, Korlina E, Gunaeni N, Duriat AS. 1993. Surveys of shallot viruses in several locations in Brebes Regency, Central Java. Bul Penelitian Hortikultura 26 (1): 97-106.

Swari FSP, Subandiyah S, Hartono S. 2015. Detection and identification of viruses infecting shallot crops in Bantul District, Yogyakarta. Pros Sem Nas Masy Biodiv Indon 1: 961-968.

Tamura K, Stecher G, Peterson D, Filipski A, Kumar S. 2013. MEGA6: Molecular evolutionary genetics analysis version 6.0. Mol Biol Evol 30 (12): 2725-2729.

Verma RK, Mishra R, Petrov NM, Stoyanova M, Stoev A, Valentinova N, Bakardjieva, Gaur RK. 2015. Molecular characterization and recombination analysis of an Indian isolate of Onion yellow dwarf virus. Eur J Plant Pathol 107: 677-684.

Wulandari AW, Hidayat SH, Sobir. 2015. Deteksi virus pada bawang merah (Allium cepa var. ascalonicum) dengan metode Dot Immuno Binding Assay. J Hort 14 (4): 350-356. 